\title{
Effect of Bt-176 maize pollen on first instar larvae of the Peacock butterfly (Inachis io) (Lepidoptera; Nymphalidae)
}

\author{
Martin FeLKE ${ }^{1 *}$, Gustav-Adolf LANGenBRUCH ${ }^{1}$, Simon FeierTAG ${ }^{1}$ and Adane KASSA ${ }^{2}$ \\ 1 Federal Research Centre for Cultivated Plants - Julius Kühn Institute, Institute for Biological Control, Heinrichstrasse 243, \\ 64287 Darmstadt, Germany \\ 2 Pioneer Hi-Bred International, Plant Protection, 7250 NW 62nd Ave., P.O. Box 552, Johnston, IA 50131, USA
}

\begin{abstract}
More than 10 years after registration of the first Bt maize cultivar in Europe, there still exists a remarkable lack of data on effects on Lepidoptera which would be necessary for a complete and comprehensive environmental risk assessment. So far only very few European butterfly species have been tested in this aspect. In our study the effect of transgenic Bacillus thuringiensis (Bt) maize pollen (event Bt-176) on the development and survival of neonate larvae of the Peacock butterfly, Inachis io (L.) was for the first time shown. The results of our study suggest that the Peacock butterfly may serve as a model organism for assessing potential side effects of new developed transgenic Bt crops on non-target butterflies in a GMO environmental risk assessment. The study was done under laboratory conditions by exposing larvae of the Peacock butterfly to various pollen doses of transgenic maize event Bt-176 (cv. PACTOL CB) or the conventional isogenic maize (cv. PACTOL) using a nochoice test. Larvae feeding for $48 \mathrm{~h}$ on nettle plants (Urtica dioica) that were contaminated with higher pollen concentrations from Bt-176 maize (205 and 388 applied pollen.cm ${ }^{-2}$ ) suffered a significantly higher mortality rate (68 and $85 \%$ respectively) compared to larvae feeding on leaves with no pollen (11\%), or feeding on leaves with pollen from conventional maize (6 to 25\%). At lower Bt maize pollen doses (23-104 applied pollen.cm ${ }^{-2}$ ), mortality ranged from $11-25 \%$ and there were no apparent differences among treatments. The corresponding $\mathrm{LC}_{50}$-and $\mathrm{LC}_{90}$-values for neonate larvae of the Peacock butterfly were 187 and 448 applied pollen grains.cm ${ }^{-2}$ of Bt-176, respectively. Weight of larvae surviving consumption of Bt-176 maize pollen declined between 10 and $81 \%$ with increased pollen doses $(r=-0.95)$. The highest weight reduction $(81 \%)$ corresponded to the highest pollen concentration ( 388 pollen grains applied. $\mathrm{cm}^{-2}$ ). Ingestion of pollen from the conventional maize hybrid did not have negative effects on larval weight gain or survival rate.
\end{abstract}

Keywords: Peacock butterfly / Cry1Ab-toxin / transgenic crops / Bt-176 / environmental risk assessment

\section{INTRODUCTION}

For the last decade there has been a steady increase in the global hectares of transgenic field crops grown. In 1998 it was estimated that there were about 28 million ha of transgenic crops grown worldwide, excluding China (James, 1998). In 2008 the global area of genetically modified crops reached 125 million hectares and worldwide 13.3 million farmers from 25 countries planted transgenic crops (James, 2008). Insect resistance, based on Bacillus thuringiensis Berliner (Bt) delta-endotoxins is still the second most widely used trait (after herbicide resistance) in genetically modified (GM) crops (James, 2003, 2008). Transgenic maize expressing Cry 1 Ab pro-

* Corresponding author: martin.felke@jki.bund.de tein, derived from the soil bacterium $B$. thuringiensis kurstaki was developed to control the European corn borer, Ostrinia nubilalis Hübner, which is one of the major maize pests in the USA and many other regions of the world (Bagrintseva et al., 2004; Ivezic and Raspudic, 2004; Lisowicz, 2003; Rice and Ostlie, 1997; Velasco et al., 2007). Bt maize expresses the insecticidal $\delta$ endotoxin Cry $1 \mathrm{Ab}$ in various plant tissues. This Cry protein acts selectively against larvae of some families in Lepidoptera (for example Pieridae and Nymphalidae). Because of this selectivity the effects on non-target organisms were not considered at the early stages of GM maize development (Pilcher and Rice, 1998). However, the work of (Losey et al., 1999) demonstrated that pollen from the transgenic maize hybrid N 4640 (event Bt-11) 
could be hazardous to the larvae of the monarch butterfly, Danaus plexippus (L.). Subsequent field and laboratory studies confirmed the possibility that pollen from $\mathrm{Bt}$ maize could have adverse effects on caterpillars of other butterfly species as well (Felke and Langenbruch, 2001; Hansen and Obrycki, 2000; Hellmich et al., 2001; Lang and Vojtech, 2006; Zangerl et al., 2001). But so far effects of Bt maize pollen have been tested only on very few butterfly species and even more than 10 years after cultivation of the first $\mathrm{Bt}$ maize cultivar, there still exists a remarkable lack of data on effects on Lepidoptera which would be necessary for a complete and comprehensive environmental risk assessment (Lang and Otto, 2010). Therefore studies on sensitivity of more butterfly species on Bt maize pollen are essential.

Although the steady growth in global planting of GM plants attests to their usefulness for many farmers and their acceptance in many markets, the imposition of the moratoria in several countries reflects the scepticism and public concern about a range of issues around GM crops, including potential impact on the environment, ecosystem and human health (Braun, 2001; Dale, 1999; Liu et al., 2005; Wolfenbarger and Phifer, 2000). Considering these public concerns, the European Parliament prescribed a risk assessment for GM crops prior to commercial cultivation (EC, 2001, 2003). The principles regulating the deliberate release into the environment of GMOs are laid down in Council Directive 2001/18/EC (EC, 2001). This Directive puts in place a step-by-step approval process made on a case-by-case assessment of the risk to human health, non-target organisms and the environment before any GMOs can be released into the environment, or placed on the market as, or in, products. An assessment of the possible immediate and/or delayed environmental impact resulting from direct and indirect interactions of the GMO with non-target organisms, including impact on population levels of competitors, herbivores, symbionts, predators, parasites and pathogens is required (EFSA, 2006). According to the (EFSA, 2006) guidance document assessors should use a tiered approach to this environmental risk assessment, first identifying potential hazards in controlled tests and then evaluating exposure in the field in order to estimate potential risks. If first tier tests do not identify sensitivity in exposed species then second and third tier test may not be required. In this context our laboratory studies with the Peacock butterfly have to be considered as first tier tests. The Peacock butterfly is common in central Europe and caterpillars are abundant during the shedding of maize pollen (Settele et al., 2005). The nettle, Urtica dioica (L.) is their only host plant and is commonly found in agricultural habitats (Ebert and Rennwald, 1991). Because of the species life cycle and habitat preferences, exposure of Peacock butterfly larvae to Bt maize pollen is possible under field conditions. Therefore, assessing the impact of Bt-maize cultivation on Inachis io is indispensable. We assessed, for the first time, the impact of transgenic maize pollen (event Bt-176) on the development and survival of neonate larvae of the Peacock butterfly in the laboratory. This transgenic maize event expresses a high level of Cry1 Ab toxin in pollen grains (Lang et al., 2004; StanleyHorn et al., 2001). In 2003 it was planted for example on 32000 ha in Spain (Lumbierres et al., 2004). In Europe Bt-176 maize was registered by the European Community from January 1st 1997 to April 18th 2007. Nowadays Bt-176 maize is no longer cultivated in Europe nor in the rest of the world.

Previously, we demonstrated the susceptibility of older stages of Peacock butterfly larvae to Bt-176 maize pollen (Felke and Langenbruch, 2003). Therefore, the aim of the current study focuses to assess the effect of Bt-176 maize pollen and the isogenic, non-transgenic cultivar on mortality and growth rate of neonate larvae of the Peacock butterfly. We included the isogenic cultivar to rule out the possibility that this cultivar had adverse effects. The possibilities of using the Peacock butterfly as a model organism in a European GMO risk assessment are discussed.

The following objectives should be tested in this study:

- Effect of Bt-176 maize pollen on mortality and growth rate of neonate $I$. io larvae;

- Effect of maize pollen of the isogenic, non-transgenic cultivar on mortality and growth rate of neonate Peacock butterfly larvae to rule out the possibility that this cultivar had adverse effects;

- How is the susceptibility of neonate Peacock butterfly larvae to Bt-176 maize pollen compared to older larval stages of this species?

- Can the Peacock butterfly serve as a model organism in a European GMO risk assessment?

\section{RESULTS}

Differences between treatments with respect to mortality rate of neonate Peacock butterfly larvae $(F=11.35$; df $=10 ; P<0.0001)$ and larval weight gain $(F=17.26$; $\mathrm{df}=10 ; P<0.0001)$ were significant. Mortality of Peacock butterfly larvae increased when exposed or fed 205 and 388 applied pollen grains.cm ${ }^{-2}$ (Fig. 1). However, mortality from these concentrations was not significantly different from each other but differed significantly from $\mathrm{cv}$. PACTOL pollen grain concentrations and the untreated control (Fig. 1). The mortality of larvae that received between 23 and 104 applied pollen grains. $\mathrm{cm}^{-2}$ from Bt-176 maize ranged from 11.3 to $25 \%$ and did not differ significantly from the untreated 


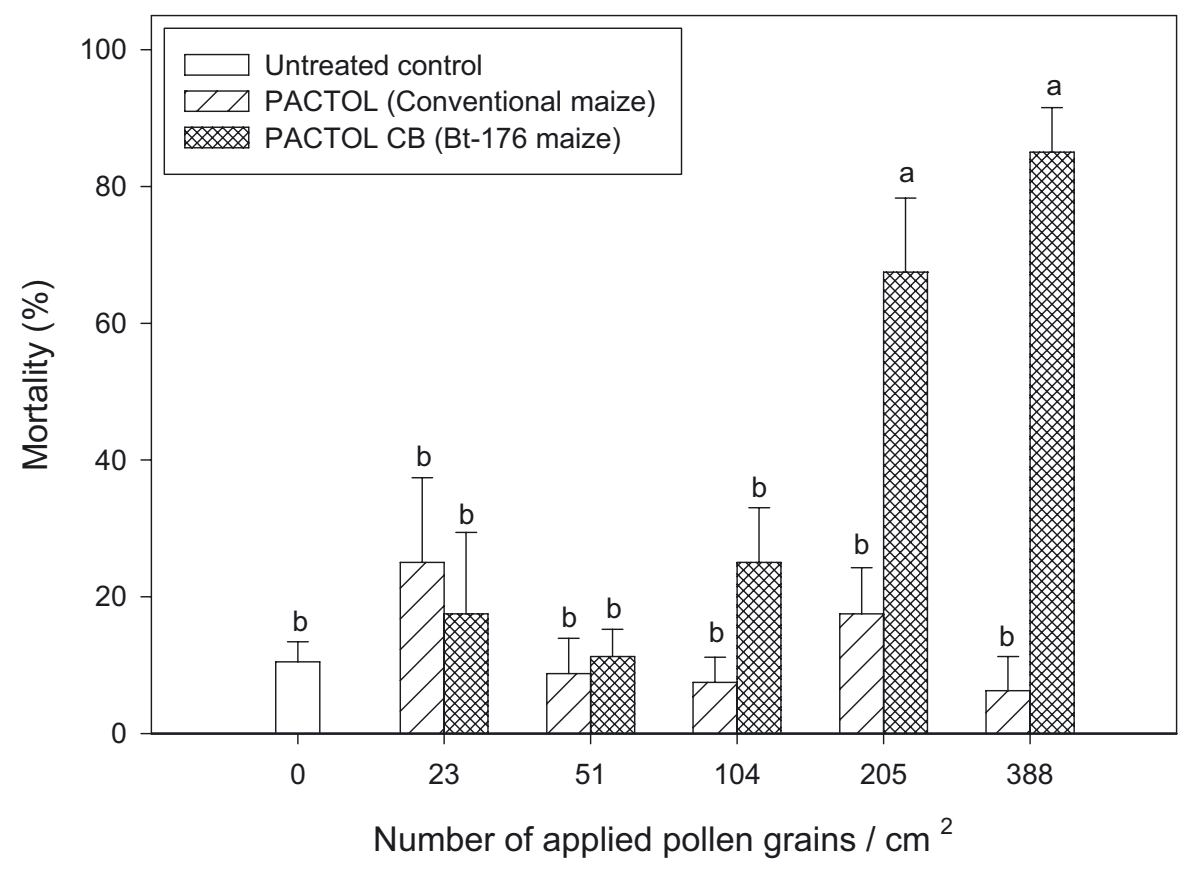

Figure 1. Average mortality (\%) for 1 st instar larvae of the Peacock butterfly exposed to various pollen grain concentrations of transgenic and non transgenic maize after $7 \mathrm{~d}$. Bars with the same letter are not statistically different (One-way ANOVA, $F=17.26$; df $=10 ; P<0.0001$, Student Newman Keuls test). Error bars represent standard error of the mean.

control (mortality $=10.5 \%$ ) and from the conventional maize pollen (mortality ranged from 6.3 to $25 \%$ ). The parameters of the probit analysis of Bt-176 maize pollen applied. $\mathrm{cm}^{-2}$ and mortality of neonate Peacock butterfly larvae are presented in Table 1 . The $\mathrm{LC}_{50^{-}}$and $\mathrm{LC}_{90^{-}}$ values for larvae were 186.8 (95\% $\mathrm{CL}=159.8-215.08)$ and 448 (95\% CL $=361.68-633.04)$ applied Bt pollen grains. $\mathrm{cm}^{-2}$, respectively. Pollen from Bt-176 maize had a significant influence on weight gain $(Y=-0.006 x+$ 2.638; $r=-0.95 ; R^{2}=0.9 ; P=0.0038$ ) (Figs. 2 and 3 ). Ingestion of transgenic maize pollen reduced larval weight 10 to $81 \%$ depending on the amount of pollen used. The highest weight reduction corresponded to the highest pollen concentrations applied (Figs. 2 and 3). The weight reduction that occurred at the lowest concentration (23 Bt-176 applied pollen grains. $\mathrm{cm}^{-2}$ ) was not different from the control and from the conventional maize pollen treatments. Moreover, there were no significant differences between the five different conventional maize pollen concentrations and the untreated control with respect to larval weight gain (Fig. 2).

\section{DISCUSSION}

Our study demonstrated for the first time the impact of transgenic $\mathrm{Bt}$ maize pollen on the development and survival of 1st instar larvae of the Peacock butterfly. Results demonstrated that growth and survival of the larvae was influenced by Bt-176 maize pollen consumption. A dose response relationship study revealed that with increasing pollen doses, larval survival rate and weight gain decreased significantly. The ingestion of pollen from a conventional maize hybrid obviously did not have a negative effect on larval development. Similar results have been reported from studies on other Lepidoptera species (Felke et al., 2002; Hellmich et al., 2001; Losey et al., 1999; Wraight et al., 2000). Our study shows, that the negative impacts on caterpillars after consumption of pollen from transgenic Bt maize is not caused by the occurrence of foreign material on their food plants (pollen), but from the Cry $1 \mathrm{Ab}$ toxin contained in this pollen.

The estimated $\mathrm{LC}_{50^{-}}$and $\mathrm{LC}_{90}$-values reported refer to the number of applied pollen grains. $\mathrm{cm}^{-2}$ leaf disc and not to the number of ingested pollen grains.larva ${ }^{-1}$. It is possible with our methodology that in the same replicate some individuals consumed more pollen grains than others. Previous attempts to provide a small leaf disk covered evenly with pollen for single larvae failed, so one replicate always consisted of a group of 10 individuals feeding from a larger leaflet. Ingestion rate of caterpillars decreased with increasing pollen doses and in treatments with higher pollen doses the applied pollen was not consumed completely. This may indicate that the $\mathrm{LC}_{50}$-value 


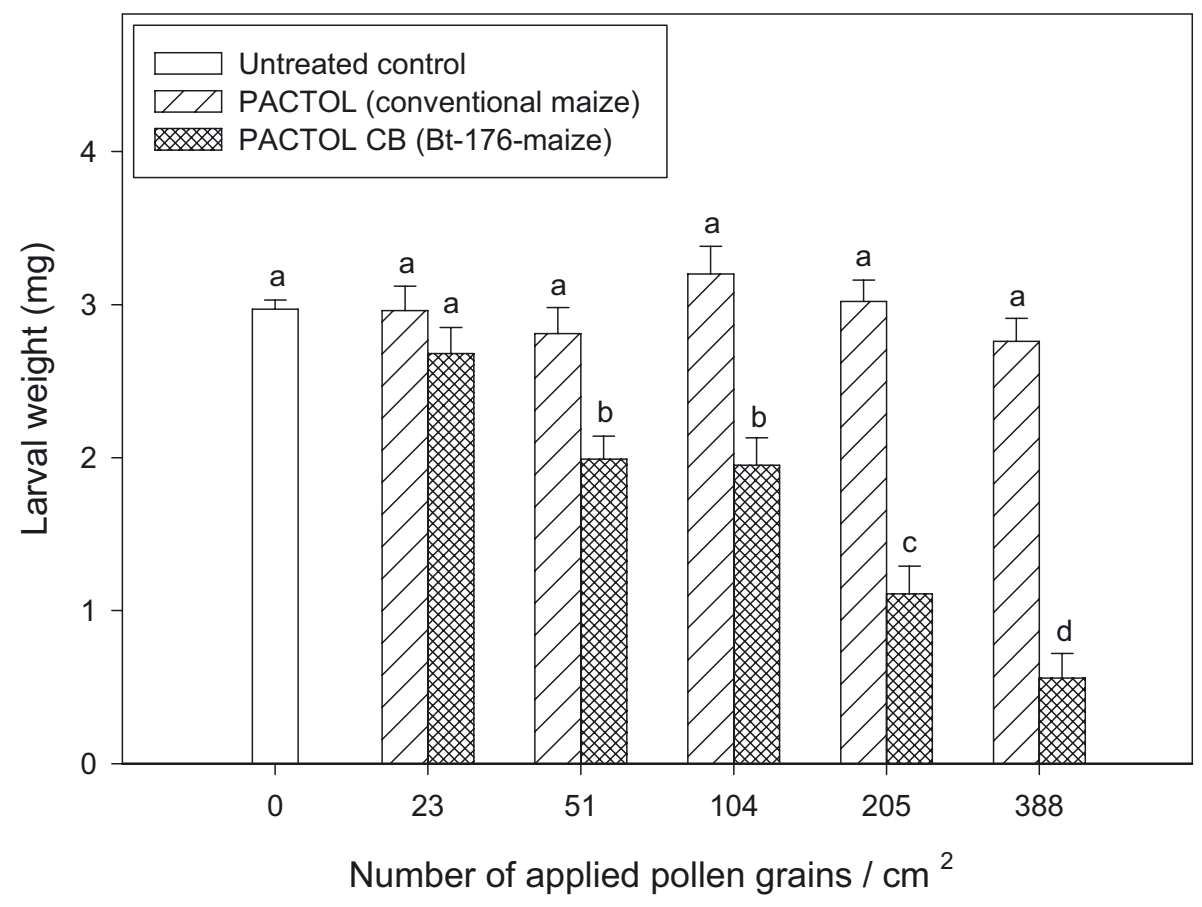

Figure 2. Average weight $(\mathrm{mg})$ for 1 st instar larvae of the Peacock butterfly exposed to various pollen grain concentrations of transgenic and non transgenic maize after $7 \mathrm{~d}$. Bars with the same letter are not statistically different (One-way ANOVA, $F=11.35$; df $=10 ; P<0.0001$, Student Newman Keuls test). Error bar represents standard error of the mean.

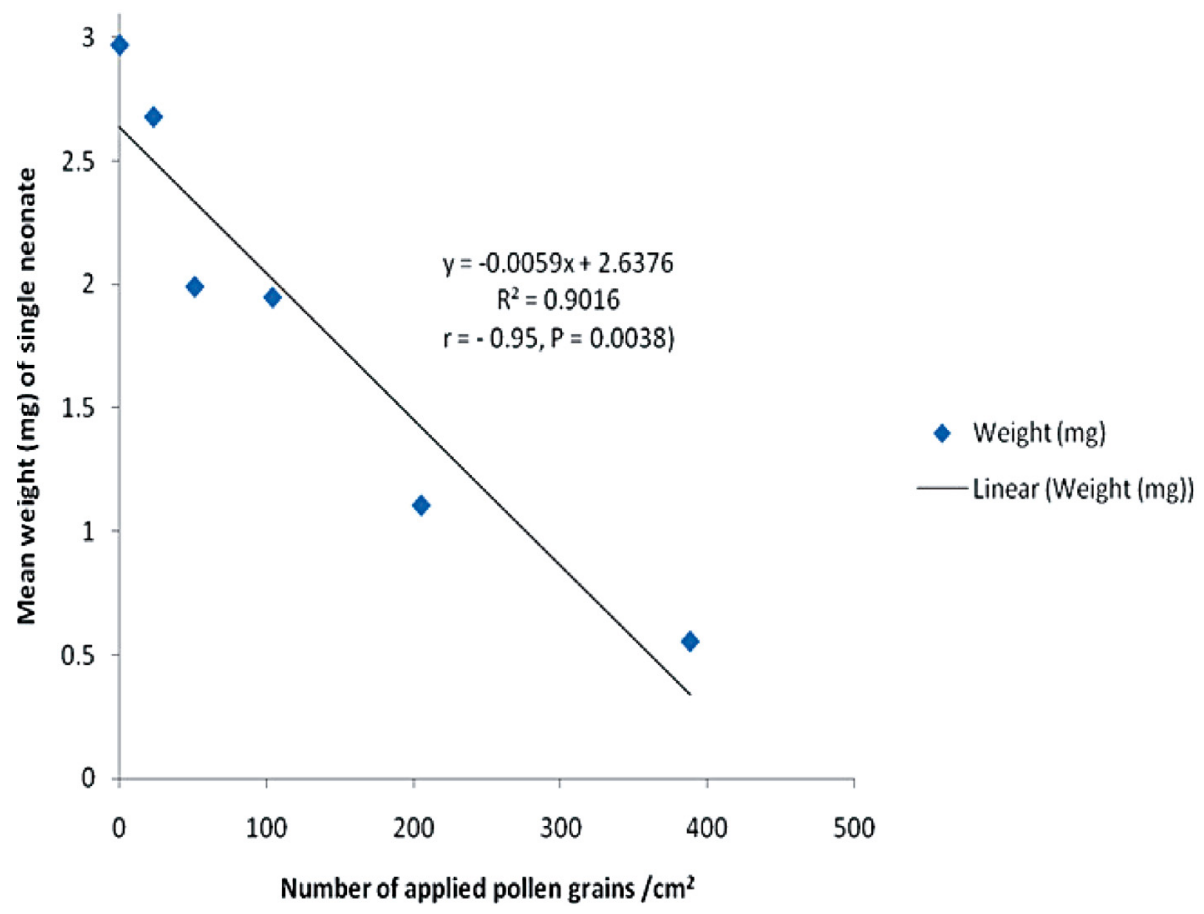

Figure 3. Relationship between Bt-176 maize pollen applied.cm ${ }^{-2}$ and mean weight $(\mathrm{mg})$ of neonate Peacock butterfly larvae after $7 \mathrm{~d}$. Each value is mean of 12 to 358 surviving larvae depending on pollen doses $(N=6 ; F=36.64 ; P=0.0038)$. 
Effect of Bt-maize on larvae of the Peacock butterfly

Table 1. Pollen dose and mortality relationship of Peacock butterfly larvae exposed in groups of 10 individuals for $48 \mathrm{~h}$ to various pollen grain concentrations of Bt-176 maize. Values are based on $\log _{10}$ of pollen grain concentration applied.cm ${ }^{-2}$.

\begin{tabular}{cccccccc}
\hline & & \multicolumn{7}{c}{ LC $_{50}$} & & & \\
Treatment & $n$ & Slope & $(95 \% \mathrm{CL})$ & $(95 \% \mathrm{CL})$ & Intercept & $P$ & $\chi^{2}$ \\
\hline Bt-176 & & $5.789 \pm$ & 2.27 & 2.65 & -13.149 & & \\
maize & 400 & 0.83 & $(2.20-2.33)$ & $(2.56-2.80)$ & \pm 1.92 & $<0.0001$ & 48.92 \\
\hline
\end{tabular}

Table 2. $\mathrm{LC}_{50}$ values (number of applied Bt-176 maize pollen grains per $\mathrm{cm}^{2}$ ) for neonate larvae of different butterfly species.

\begin{tabular}{cccc}
\hline Species & LC $_{50}$ & Cultivar & Reference \\
\hline Papilio machaon & $92.3(17.7)^{\mathrm{a}}$ & NAVARES & Lang and Vojtech (2006) \\
Inachis io & 186.8 & PACTOL CB & this study \\
Danaus plexippus & 389 & Maximizer 357 & Sears and Stanley-Horn (2000) \\
Papilio polyxenes & 613 & Max 454 & Zangerl et al. (2001) \\
\hline
\end{tabular}

${ }^{\text {a }} \mathrm{LD}_{50}$-value in brackets refers to the number of ingested pollen.individual ${ }^{-1}$.

based on ingested pollen numbers will be lower than the given number of 186.8 applied pollen grains.cm ${ }^{-2}$. Lang and Vojtech (2006) compared LC $_{50}$ values for Papilio machaon L. based on applied and ingested pollen numbers. Their findings demonstrated that $\mathrm{LC}_{50}$-values calculated for the number of applied pollen grains. $\mathrm{cm}^{-2}$ was about five times higher than the $\mathrm{LC}_{50}$-values based on the number of ingested pollen grains.

It could be proved in our study that 50 applied pollen grains. $\mathrm{cm}^{-2}$ cause significant sublethal effects on 1 st instar larvae of the Peacock butterfly. Because application of 200 or more pollen grains. $\mathrm{cm}^{-2}$ led to a significant increase in mortality, Peacock butterfly larvae seem to be less sensitive to pollen from Bt-176 maize than 1st instar larvae of P. machaon (Lang and Vojtech, 2006) but more susceptible than neonate caterpillars of Danaus plexippus (Sears and Stanley-Horn, 2000) or Papilio polyxenes Fabricius, 1775 (Zangerl et al., 2001). A summery of $\mathrm{LC}_{50}$-values of neonate larvae from various butterfly species related to $\mathrm{Bt}-176$ maize pollen consumption is presented in Table 3. Lang and Vojtech (2006) estimated $\mathrm{LC}_{50}$-values for neonate larvae of Papilio machaon based on pollen density. $\mathrm{cm}^{-2}$ and on the number of ingested pollen grains.individual ${ }^{-1}$ (see Tab. 2).

The results reported in the current study are based on a $48 \mathrm{~h}$ acute exposure of neonate $I$. io larvae to pollen numbers that would otherwise occur inside or in the vicinity of a blooming maize field (Senior Author, personal observation). Due to the nature of the experimental arena used in the current study, keeping the same leaf disc more than $48 \mathrm{~h}$ would result in increased fungal contamination which may confound the results. However, since in the field maize usually sheds pollen for about seven days in average, future studies should consider to address the effect of chronic exposure on larval mortality and weight gain, adult fitness and fecundity or generational fitness of the Peacock butterfly.

In comparison to older Peacock butterfly larvae, neonates are more susceptible to Bt-176 maize pollen. The $\mathrm{LD}_{50}$-value for 2 nd instar Peacock butterfly larvae was 61.4 pollen grains of the Bt-176 hybrid PACTOL $\mathrm{CB}$ applied per individual which corresponds to a pollen density of about 241 pollen grains. $\mathrm{cm}^{-2}$ (Felke and Langenbruch, 2003). Fourth instar were even less sensitive and estimation of the $\mathrm{LD}_{50}$-value was not possible. Ingestion of 80 pollen grains.individual ${ }^{-1}$ did not cause increased mortality (Felke and Langenbruch, 2003). Generally, within the same lepidopteran species older larvae are less sensitive to $\mathrm{Bt}$ toxins than younger ones (Krieg and Langenbruch, 1981). Differences in susceptibility to Bt pollen between younger and older larvae have been reported for Danaus plexippus (Hellmich et al., 2001), Pieris rapae (L.) and P. brassicae (L.) (Felke and Langenbruch, 2001).

Several aspects have to be considered to assess the possible impact of $\mathrm{Bt}$ maize on nontarget butterfly species. The acute toxic effect of $\mathrm{Bt}$ maize pollen on caterpillars can be determined during laboratory assays. Another crucial point is the degree to which larvae would be exposed to toxic amounts of Bt pollen. In central Europe larvae of the Peacock butterfly can be found mainly in July and August (Ebert and Rennwald, 1991). This means that occurrence of larvae of the second generation is overlapping with maize pollen shed, which usually starts in July in Germany (Lang et al., 2004). Caterpillars of the Peacock butterfly are feeding exclusively on the common nettle plant $(U$. dioica) which is quite common in agriculturally used areas. Larval habitats can be situated close to maize fields because sun-exposed groups of nettle plants are known to be the typical larval 
habitat of this butterfly species (Ebert and Rennwald, 1991; Korneck and Pretscher, 2001; Lang et al., 2004).

Nettle are effective maize pollen collectors (own observations). Maize pollen can be dispersed very effectively by wind, but references regarding pollen dispersion vary. Generally pollen deposition decreases with increasing distance to the field's edge. Pleasants et al. (2001) found 63.1 maize pollen. $\mathrm{cm}^{-2}$ on potted milkweeds which had been placed directly on the edge of a blooming maize field. Inside the field pollen concentration was much higher matching on average 170.6 pollen grains. $\mathrm{cm}^{-2}$. Wraight et al. (2000) collected pollen grains by using sticky slides and found an average of up to 210 pollen grains in direct vicinity (half a meter) from the edge of a blooming maize field. Using the same method, Lang et al. (2004) estimated the maximum pollen. $\mathrm{cm}^{-2}$ at various distances from the edge of maize fields (Bt-176, cv. NAVARES). Four meters inside a blooming maize field the maximum pollen number. $\mathrm{cm}^{-2}$ was 429 . Lang et al. (2004) also recorded pollen numbers from the field's edge $(\cong 270)$ and at a distance of $1 \mathrm{~m}(\cong 160), 3 \mathrm{~m}$ $(\cong 160), 5 \mathrm{~m}(\cong 60), 6 \mathrm{~m}(\cong 150)$ and $10 \mathrm{~m}(\cong 80)$ to the maize field margin. These field observations on maize pollen dispersion show that neonate larvae of the Peacock butterfly can be confronted with lethal pollen doses if they are feeding on nettle growing inside or in direct vicinity of a blooming Bt-176 maize field. Sublethal effects like reduced weight gain could be expected up to a distance of at least $10 \mathrm{~m}$ from the edge of a blooming maize field.

Bt-176 maize was registered by the European Community from January 1st 1997 to April 4th 2007. Nowadays Bt-176 maize is no longer cultivated in Europe nor in the rest of the world. Nevertheless it is important from our point of view to present the results from this study as effects of Bt maize pollen on caterpillars have so far been reported only for a handful of species. Based on the few existing data on effects on Lepidoptera a complete and comprehensive environmental risk assessment is still not possible (Lang and Otto, 2010). One major goal of this study was to complete the sensitivity study of Peacock butterfly to Bt-176 maize pollen. Previously, Felke and Langenbruch (2003) studied susceptibility of 2 nd and 4th instar larvae to $\mathrm{Bt}$ maize pollen. Our results suggest that the Peacock butterfly could be used as a model organism for an European environmental risk assessment (ERA) to investigate potential side effects of new Bt-maize variants on non-target butterflies in the laboratory as well as in the field because of the following aspects:

- Neonate larvae of the Peacock butterfly are highly susceptible to the Cry1 Ab toxin which is produced in pollen of different Bt-maize events.

- The Peacock butterfly (Inachis io) is common in Europe.
- The Peacock butterfly is quite common in agricultural settings.

- The biology of this species is well known.

- Larvae of the Peacock butterfly feed on only one host plant (Urtica dioica).

- Identification and recording of adults and larvae is simple.

- The species has distinct and non-overlapping generations.

- Maize pollen exposure to Peacock butterfly larvae is very likely for many parts of Europe.

- Rearing of the Peacock butterfly under semi-natural conditions is simple.

\section{MATERIAL AND METHODS}

\section{Insect sources}

A laboratory colony of the Peacock butterfly was established from larvae collected near Darmstadt (state of Hesse, Germany) in May 2002. Adults were placed in mating cages measuring $2 \times 2 \times 2 \mathrm{~m}$, containing potted nettle plants $(U$. dioica $)$. The butterflies were provided with a $10 \%$ honey solution and laid their eggs on nettle plants (Felke, 2003). The clusters of eggs were kept in the same cage for hatching; however, in some cases parts of the nettle plants containing the eggs were transferred to a climate chamber $\left(15^{\circ} \mathrm{C}\right)$ to slow down their development. First instars $(<24 \mathrm{~h}$ old $)$ were used for bioassays.

\section{Pollen sources}

Pollen from PACTOL CB (Bt-176 maize) and the conventional isogenic maize cultivar PACTOL were used. Both cultivars were produced and distributed by SYNGENTA SEEDS (Germany). The transgenic maize event Bt-176 contains a maize pollen specific promoter and a phosphoenolpyruvate carboxylase promoter. Cry1 Ab-toxin is expressed in pollen and photosynthetic tissues (Koziel et al., 1993). Transgenic and non-transgenic pollen grains were collected from greenhouse-grown maize by gently tapping the spatula of a blooming plant. Immediately after collection pollen was sieved through a $0.1 \mathrm{~mm}$ mesh to remove contaminants.

Only fresh pollen was used for the bioassays. Toxin content of the PACTOL CB pollen grains used for this study was not determined. The Bt-176 maize cultivar NAVARES contains $2.59 \pm 0.40 \mathrm{mg}$ Cry $1 \mathrm{Ab}$ protein per g dry weight pollen (Lang et al., 2004). Sears and StanleyHorn (2000) report that Bt-176 maize pollen contains on average between 1.4 and $2.3 \mathrm{Cry} 1 \mathrm{Ab}$ protein. $\mathrm{g}^{-1}$ pollen. 
Table 3. Average number of pollen grains ( $\pm \mathrm{SE}$ ) counted per $0.5 \mu \mathrm{L}$ drop of different pollen suspensions and pollen numbers applied per $\mathrm{cm}^{2}$ leaf disk. ( $N=5$, SE: standard error of the mean.)

\begin{tabular}{ccc}
\hline $\begin{array}{c}\text { Pollen (mg) per } \\
\mathbf{1} \mathbf{~ m L} \text { of tap water }\end{array}$ & $\begin{array}{c}\text { Number of pollen grains }( \pm \mathbf{S E}) \mathbf{p e r} \\
\mathbf{0 . 5} \boldsymbol{\mu} \mathbf{L}^{\mathrm{a}}\end{array}$ & $\mathbf{C m}^{2 \mathrm{~b}}$ \\
\hline 2.5 & $4.7 \pm 0.5$ & $23.3 \pm 2.5$ \\
5 & $10.2 \pm 1.6$ & $50.8 \pm 8.0$ \\
10 & $20.8 \pm 1.6$ & $104.2 \pm 7.9$ \\
20 & $41.0 \pm 2.8$ & $205.0 \pm 14.0$ \\
40 & $77.7 \pm 3.1$ & $388.3 \pm 15.7$ \\
\hline
\end{tabular}

a Values are average of five observations.

${ }^{b}$ Values are estimated from the number of drops $(10 \times 0.5 \mu \mathrm{L})$ applied on $2 \mathrm{~cm}^{2}$ leaf surface.

Different amount of pollen was suspended in $1 \mathrm{~mL}$ of tap water and mixed by gently shaking the tubes. Subsequently, 10 drops each with $0.5 \mu \mathrm{L}$ of a defined pollen solution was applied evenly on leaf discs $\left(2 \mathrm{~cm}^{2}\right)$ of $U$. dioica. The number of pollen grains per $0.5 \mu \mathrm{L}$ pollen solution was assessed at the beginning of the study by taking five random samples. The resulting pollen numbers after application on the leaf varied on average from 23 (lowest pollen concentration) to 388 (highest pollen concentration) applied pollen grains. $\mathrm{cm}^{-2}$ (Tab. 3).

Pollen contaminated leaves were then placed individually in a Petri-dish $(3-\mathrm{cm} \phi)$ filled with $2 \%$ agar medium to keep the leaves fresh. After the leaves were dry, 10 larvae were placed on each leaf disc by using a fine brush. Petri dishes were covered with towel paper and incubated at $25^{\circ} \mathrm{C} / 15^{\circ} \mathrm{C}$ (day/night) and L:D $16 / 8 \mathrm{~h}$ for $7 \mathrm{~d}$. Controls had $U$. dioica leaf discs without pollen. Insects were monitored daily and if the leaf discs were consumed within the first $24 \mathrm{~h}$ they were replaced with fresh untreated ones. After $48 \mathrm{~h}$, remains of pollen treated leaves in all treatments were removed and the insects were provided ad libitum with fresh and untreated discs. Mortality was recorded daily and surviving larvae were weighed $7 \mathrm{~d}$ post-treatment. The bioassay consisted of three treatments: conventional maize (cv. PACTOL) and Bt-maize (cv. PACTOL CB) each with five different pollen concentrations and the control (5 replications with 10 larvae each). The experiment was repeated eight times between 22nd of July and 1st of August 2002.

\section{Statistical analysis}

Percentage mortality and weight gain were arcsine transformed and subjected to one-way analysis of variance using the general linear model procedure (PROC GLM). Similarly, larval weight $(\mathrm{mg})$ of all surviving individuals (measured separately) were subjected to one-way ANOVA (PROC GLM) (SAS Institute, 2003). In all cases, means were separated using a Student Newman Keuls test (SAS Institute, 2003). Subsequently, correlation analyses were performed for the mean weight $(\mathrm{mg})$ of the neonates and the Bt-176 maize pollen doses. Observed mortality was corrected for the corresponding control mortality (Abbott, 1925) and probit analysis (PROC PROBIT) was used to estimate the $\mathrm{LC}_{50}$ - and $\mathrm{LC}_{90}$-values with $95 \%$ confidence limits (SAS Institute, 2003).

\section{ACKNOWLEDGEMENTS}

We thank I. Löffler and A. Kromm for technical assistance in the laboratory. We would also like to thank Dr. B.L. Parker (University of Vermont), Dr. J. Schiemann (JKI Braunschweig) and Dr. A. Lang (University of Basel) for reading and commenting an earlier draft of the manuscript. The study was financially supported by the German Umweltbundesamt (FKZ 20167 430/05). Syngenta Seeds (Bad Salzufflen) provided seeds of all maize varieties used in this study.

Received November 20, 2008; accepted December 5, 2009.

\section{REFERENCES}

Abbott WS (1925) A method of computing the effectiveness of an insecticide. Econ. Entomol. 18: 265-267

Bagrintseva VN, Borshch TI, Shtain SE, Chebykina LA (2004) Dangerous pests of maize. Zashchita $i$ Karantin Rastenii 5: 34

Braun R (2001) Why are Europeans scared of biotech food? Agro Food Industry Hi-Tech 12: 32-34

Dale PJ (1999) Public reactions and scientific responses to transgenic crops. Current Opinion in Biotechnology 10: 203208

Ebert G, Rennwald E (1991) Die Schmetterlinge BadenWürttembergs. Band 1: Tagfalter I. Eugen Ulmer Verlag, Stuttgart, Germany

EC (2001) Directive 2001/18/EC of the European Parliament and of the Council of 12 March 2001 on the deliberate release into the environment of genetically modified organisms and repealing Council Directive 90/220/EEC. Official Journal of the European Communities L 106: 1-39

EC (2003) Regulation (EC) 1829/2003 of the European Parliament and of the Council of 22 September 2003 on genetically modified food and feed. Official Journal of the European Communities L 268: 1-23

EFSA (2006) Guidance document of the Scientific Panel on Genetically Modified Organisms for the risk assessment of genetically modified plants and derived food and feed. EFSA Journal 99: 1-100 
Felke M (2003) Massenzucht von Aglais urticae Linnaeus 1758 und Inachis io Linnaeus 1758 (Lepidoptera, Nymphalidae) unter freilandnahen Bedingungen. Entomologische Zeitschrift 113: $211-213$

Felke M, Langenbruch GA (2001) Gefährdet Bt-Pollen Schmetterlinge? Gesunde Pflanzen 53: 24-28

Felke M, Langenbruch GA (2003) Wirkung von Bt-MaisPollen auf Raupen des Tagpfauenauges im Laborversuch. Gesunde Pflanzen 55: 1-7

Felke M, Lorenz N, Langenbruch GA (2002) Laboratory studies on the effects of pollen from Bt-maize on larvae of some butterfly species. J. Appl. Ent. 126: 320-325

Hansen Jesse LC, Obrycki JJ (2000) Field deposition of Bt transgenic corn pollen: lethal effects on the monarch butterfly. Oecologia 125: 241-248

Hellmich RL, Siegfried BD, Sears MK, Stanley-Horn DE, Daniels MJ, Mattila HR, Spencer T, Bidne KG, Lewis LC (2001) Monarch larvae sensitivity to Bacillus thuringiensis-purified proteins and pollen. Proceedings of the National Academy of Sciences of the United States of America 98, pp 11925-11930

Ivezic M, Raspudic E (2004) Economic corn pests on the territory of eastern Croatia. Razprave - Razred za Naravoslovne Vede, Slovenska Akademija Znanosti in Umetnosti 45: 87-98

James C (1998) Global status and distribution of commercial transgenic crops in 1997. Biotechnol. Dev. Monit. 35: 9-12

James C (2003) Global review of commercialized transgenic crops. Current Science 84: 303-309

James C (2008) Global Status of Commercialized Biotech/GM Crops: 2008. ISAAA Brief 39, ISAAA: Ithaca, NY

Korneck D, Pretscher P (2001) Bedeutung von Saumbiotopen für Flora und Fauna. Mitt. Biol. Bundesanst. LandForstwirtsch. 387: 48-56

Koziel MG, Carozzi NB, Currier TC, Warren GW, Evola SV (1993) The insecticidal crystal proteins of Bacillus thuringiensis: Past, present and future uses. Biotech. Genet. Engineer. Rev. 11: 171-228

Krieg A, Langenbruch GA (1981) Susceptibility of Arthropod Species to Bacillus thuringiensis. In Burges D, ed, Microbial Control of Pests and Plant Diseases 1970-1980, Academic Press, London, pp 836-896

Lang A, Otto M (2010) A synthesis of laboratory and field studies on the effects of transgenic Bacillus thuringiensis (Bt) maize on non-target Lepidoptera. Entomol. Exp. Appl. 135: $121-134$

Lang A, Vojtech E (2006) The effects of pollen consumption of transgenic Bt maize on the common swallowtail, Papilio machaon L. (Lepidoptera, Papilionidae). Bas. Appl. Ecol. 7: 296-306

Lang A, Ludy C, Vojtech E (2004) Dispersion and deposition of Bt maize pollen in field margins. Journal of plant diseases and protection 111: $417-428$

Lisowicz F (2003) The occurrence, harmfulness and effectiveness of control of the European corn borer (Ostrinia nubilalis Hbn.) in maize. Ochrona Roslin 47: 11-12

Liu B, Zeng Q, Yan FM, Xu HG, Xu CR (2005) Effects of transgenic plants on soil microorganisms. Plant Soil 271: $1-13$
Losey JE, Rayor LS, Carter ME (1999) Transgenic pollen harms monarch larvae. Nature 399: 214

Lumbierres B, Albajes R, Pons X (2004) Transgenic Bt maize and Rhopalosiphum padi (Hom., Aphididae) performance. Ecol. Entomol. 29: 309-317

Pilcher CD, Rice ME (1998) Management of European corn borer (Lepidoptera: Crambidae) and corn rootworms (Coleoptera: Chrysomelidae) with transgenic corn: A survey of farmer perceptions. American Entomologist 44: 36-44

Pleasants JM, Hellmich RL, Dively GP, Sears MK, StanleyHorn DE, Mattila HR, Foster JE, Clark P, Jones GD (2001) Corn pollen deposition on milkweeds in and near cornfields. Proceedings of the National Academy of Sciences of the United States of America 98, pp 11919-11924

Rice ME, Ostlie K (1997) European corn borer management in field corn: A survey of perceptions and practices in Iowa and Minnesota. Journal of production agriculture 10: 628-634

SAS Institute (2003) SAS/STAT user's guide, 4th edition. Cary, NC, SAS Institute

Sears MK, Stanley-Horn D (2000) Impact of Bt maize pollen on monarch butterfly populations. In Fairbairn C, Scoles G, McHughen A., eds, Proceedings of the Sixth International Symposium on the Biosafety of Genetically Modified Organisms, July 2000, Saskatoon, Canada, pp 120130

Sears MK, Hellmich RL, Stanley-Horn DE, Oberhauser KS, Pleasants JM, Mattila HR, Siegfried BD, Dively GP (2001) Impact of Bt corn pollen on monarch butterfly populations: A risk assessment. Proceedings of the National Academy of Sciences of the United States of America 98, pp 11937-11942

Settele J, Steiner R, Reinhardt R, Feldmann R (2005) Schmetterlinge - Die Tagfalter Deutschlands. Eugen Ulmer Verlag, Stuttgart

Stanley-Horn DE, Dively GP, Hellmich RL, Mattila HR, Sears MK, Rose R, Jesse LCH, Losey JE, Obrycki JJ, Lewis L (2001) Assessing the impact of Cry1Ab-expressing corn pollen on monarch butterfly larvae in field studies. Proceedings of the National Academy of Sciences of the United States of America 98, pp 11931-11936

Velasco P, Revilla P, Monetti L, Butron A, Ordas A, Malvar RA (2007) Corn borers (Lepidoptera: Noctuidae; Crambidae) in Northwestern Spain: Population dynamics and distribution. Maydica 52: 195-203

Wolfenbarger LL, Phifer PR (2000) Biotechnology and ecology - The ecological risks and benefits of genetically engineered plants. Science 290: 2088-2093

Wraight CL, Zangerl AR, Carroll MJ, Berenbaum MR (2000) Absence of toxicity of Bacillus thuringiensis pollen to black swallowtails under field conditions. Proceedings of the National Academy of Sciences of the United States of America 97, pp 7700-7703

Zangerl AR, McKenna D, Wraight CL, Carroll M, Ficarello P, Warner R, Berenbaum MR (2001) Effects of exposure to event 176 Bacillus thuringiensis corn pollen on monarch and black swallowtail caterpillars under field conditions. Proceedings of the National Academy of Sciences of the United States of America 98, pp 11908-11912 